\title{
EFISIENSI PENGEMBANGAN MEDIA PEMBELAJARAN TEMATIK SISWA KELAS II SEKOLAH DASAR DI SAMARINDA
}

\author{
Marhuma $^{1}$, Mohammad Siddik ${ }^{2}$, Budi Rahardjo ${ }^{3}$ \\ ${ }^{123}$ Universitas Mulawarman \\ rafifgalung737@gmail.com, mohammad.siddik@ffkip.unmul.ac.id, \\ budi.rahardjo@fkip.unmul.ac.id
}

\begin{abstract}
This study aims to determine the results of the analysis of the needs of teachers and students, the results of field trials, and the effectiveness test so that they produce appropriate learning thematic teaching materials. This type of research is development research that refers to the ADDIE development model. The research data were obtained from the results of interviews, observation sheets, validation sheets of thematic learning teaching materials, teacher responses and test study results. The results of the assessment of the development of thematic teaching materials, validated by experts, obtained $90 \%$ of the very valid conversion results, the analysis of student learning outcomes after using the results of developing thematic teaching materials obtained 90.04\% very effective categories. Thematic teaching materials developed by researchers use the ADDIE model that is feasible, effective and efficient to use in the learning process in elementary schools.
\end{abstract}

Keywords: Thematics, Teaching, Materials

\section{Pendahuluan}

Pendidikan memegang peranan penting dalam kehidupan, karena pendidikan merupakan wahana untuk meningkatkan dan mengembangkan kualitas sumber daya manusia (SDM). Seiring perkembangan jaman yang semakin pesat, dunia pendidikan juga berkembang semakin cepat. Pada masa sekarang ini sistem pembelajaran dikenal dengan pembelajaran tematik, sebelum pembelajaran tematik dikenal dengan kurikulum tigkat satuan pendidikan. Sedangkan pembelajaran tematik dikenal dengan kurikulum 2013. Kurikulum yang berganti seiring dengan kemajuan zaman mempunyai tujuan yang sama yaitu mencerdaskan putra putri bangsa dengan mentransfer ilmu pengetahuan kepada peserta didik.

Pembelajaran adalah serangkaian proses kegiatan yang melibatkan guru, siswa, dan komponen lainnya dalam rangka mencapai tujuan pembelajaran.Istilah pembelajaran tematik disebut juga dengan pembelajaran terpadu, yaitu pembelajaran yang menggunakan tema tertentu untuk mengaitkan antara beberapa isi mata pelajaran dengan pengalaman kehidupan sehari hari peserta didik sehingga dapat memberikan pengalaman bermakna bagi mereka.

Pembelajaran tematik di Sekolah dasar atau madrasah ibtidaiyah khususnya pada kelas bawah kelas 1,2 dan 3. Pada usia tersebut seluruh aspek perkembangan kecerdasannya tumbuh dan berkembang sangat luar biasa. Umumnya tingkat perkembangan masih memandang bahwa segala sesuatu itu holistic serta mampu memahami hubungan antara konsep secara sederhana. Proses pembelajarannya masih bergantung pada objek - objek konkrit dan pengalaman yang dialami peserta didik secara langsung. Pada dasarnya pembelajaran terpadu adalah pembelajaran yang didalamnya siswa yang aktif secara mental membangun pengetahuannya yang dilandasi oleh struktur kognitif yang telah dimilikinya.

Menurut Abdul Majid (2014:80) pembelajaran tematik merupakan salah satu model pembelajaran terpadu ( integrated instruction) yang merupakan suatu system pembelajaran yang memungkinkan siswa, baik secara individu maupun kelompok aktif menggali dan menemukan konsep serta prinsip - prinsip keilmuan secara holistic, bermakna, dan otentik.

Keberhasilan dalam proses pembelajaran ditentukan oleh pendidik yang professional, input yang baik, dan ditunjaang dengan fasilitas seperti gedung sekolah, alat - alat pengajaran dan sumber - sumber belajar. Sebagai pendidik pemilihan bahan ajar yang tepat dan berkualitas sangat penting.Bahan ajar sebagai komponen kurikulum yang akan disampaikan kepada siswa, komponen yang berperan sebagai materi pembelajaran.

Depdiknas (2008:7) bentuk - bentuk bahan ajar dapat berupa: (1) bahan cetak seperti hand out, buku, modul, lembar kerja, brosur, leaflet; (2) Audio visual,seperti video/ film, vcd; (3) audio seerti radio, kaset, $\mathrm{CD}$ audio, $\mathrm{PH}$; (4) Visual seperti foto, gambar, model/maket; (5) Multimedia seperti CD interaktif, computer 
based, internet.

Pengembangan bahan ajar penting dilakukan oleh pendidik agar pembelajaran lebih efektif, efisien, dan tidak melenceng dari komponen yang ingin dicapai. Bahan ajar merupakan segala bentuk bahan yang dapat digunakan oleh pendidik untuk membantu pelaksanaan kegiatan mengajar di kelas.

Selain itu, dalam Pembelajaran tematik kelas II pada tema kegiatanku sehari - hari dsekolah pembelajaran menulis kalimat sederhana perlu mendapat perhatian. Guru di sekolah dasar hendaknya menyadari pentingnya latihan menulis sebagai salah satu uasaha meningkatkan kemampuan berbahasa siswa. Selama ini ada kecendrungan pembelajaran terlalu diarahkan pada segi teori - teori saja dari pada latihan menulis sehingga pengajaran menulis tidak akan tercapai dengan baik tanpa adanya latihan - latihan keterampilan menulis menjadi salah satu pokok bahasan dalam pembelajaran tematik yang harus benar - benar diajarkan secara tepat.

Solchan (2011: 6.5) menyatakan bahwa pada awal masuk sekolah, sajian pembelajaran yang penting adalah membaca dan menulis. Kedua jenis keterampilan ini dikemas dalam satu paket pembelajaran yang biasa disebut MMP (Membaca dan Menulis Permulaan). Keterampilan ini menjadi awal bagi siswa dalam memperoleh pengetahuan yang lainnya. Penelitian ini akan memfokuskan pada kemampun menulis siswa.

Namun kenyataan di lapangan menunjukkan bahwa masih banyak orang yang belum terampil dalam menulis sebagai wahana untuk menyampaikan gagasan, pikiran dan perasaannya dalam bentuk tulisan. Ketidak mampuan ini dapat dilihat dari berbagai kelemahan yang ditunjukkan misalnya seseorang merasa kesulitan dalam menentukan ide yang akan dikembangkan menjadi tulisan, sedikitnya hasil tulisan yang dihasilkan seseorang. Selain itu, masih banyak kesalahan dalam menggunaan bahasa, tanda baca, penggunaan huruf kapital, penulisan singkatan, penulisan akronim dan lain sebagainya.

Menulis mempunyai beberapa tujuan yaitu penugasan, altruistic, persuasive, penerangan, pernyataan diri, tujuan kreatif dan memecahkan masalah. Menulis juga memberikan beberapa manfaat yaitu sebagai sarana untuk menemukan sesuatu, memunculkan ide-ide baru, melatih kemampuan dalam mengorganisasi dan menjernihkan berbagai konsep atau ide yang dimiliki, melatih sikap objektif yang terdapat dalam diri seseorang, membantu memecahkan masalah dan menjadikan seseorang aktif dalam memberikan informasi dan tidak hanya menjadi pihak yang menerima informasi (Tarigan, 1994: $4)$.

Santosa (2011: 5.3), pembelajaran menulis diawali dengan menulis kalimatkalimat minim, kalimat inti, kalimat sederhana, kalimat tunggal di kelas rendah, dan meningkat menjadi kalimat luas, kalimat majemuk, kalimat transformasi, sampai anak mampu merangkai kalimat menjadi sebuah wancana yang sederhana. Kebijakan pemerintah melalui Dinas Pendidikan mengharuskan sekolah untuk mengajarkan kegiatan menulis kepada peserta didik mulai dari tingkat sekolah dasar sampai tingkat sekolah menengah atas. Pembelajaran menulis yang diajarkan pada siswa kelas II Sekolah Dasar adalah menulis permulaan. Menulis permulaan merupakan dasar dan modal pertama bagi siswa untuk dapat menulis pada tingkat-tingkat berikutnya. Seperti yang diungkapkan oleh Zuhdi (2008: 13) yang menyatakan bahwa pengetahuan dan kemampuan yang didapatkan siswa dari pembelajaran menulis permulaan akan menjadi landasan pokok dalam peningkatan dan pengembangan kemampuan siswa pada jenjang selanjutnya.

Pembelajaran menulis permulaan difokuskan pada penulisan huruf, penulisan kata, penulisan kalimat sederhana dan penulisan tanda baca. Popp (2008) menyatakan bahwa pengembangan penulisan pada awalnya anakanak akan menghasilkan tulisan cakar ayam atau bentuk lingkaran, titik-titik atau kombinasi. Hal ini sering diikuti dengan penggunaan bentuk huruf dan beberapa huruf nama anak tersebut. Demikian juga anak-anak mulai memahami hubungan antara bunyi dengan simbol huruf dan dapat menggunakan pengetahuan ini untuk mengeja. Apabila pembelajaran menulis permulaan ini berjalan dengan baik dan kuat maka pengembangan keterampilan menulis tingkat selanjutnya juga akan menjadi baik.

Tugas guru dalam proses pembelajaran tidak hanya terbatas dalam penyampaian materi kepada peserta didik. Sesuai kemajuan dan tuntutan jaman, guru harus memiliki kemampuan untuk memahami karakteristik pesertadidik agar mampu membantu mereka dalam menghadapi kesulitan belajar. Dalam hal ini guru dituntut mengembangkan bahan ajar yang efektif agar dapat membimbing peserta didik secara optimal. Pelajaran akan lebih menarik apabila guru mampu mengelola kelas, 
memilih strategi, bahan pembelajaran yang tepat.

Buku cerita bergambar merupakan salah satu sumber belajar yang dapat dimanfaatkan oleh seorang pengajar dalam proses pembelajaran, salah satunya sebagai perangsang motivasi yang akan membantu siswa dalam menginterpretasikan atau memahami makna kalimat. Selanjutnya siswa akan lebih mudah dalam menulis kalimat karena telah membaca.

Berdasarkan hasil studi pendahuluan yang dilakukan peneliti lakukan di SDN.024 Samarinda Utara diperoleh data bahwa guru masih terfokus pada penggunaan buku guru dan buku siswa sebagai sumber belajar selama pembelajaran. Permasalahan ini berdasarkan hasil observasi dan wawancara dengan guru kelas II SD. Sebagian besar siswa dalam pembelajaran tematik khususnya pada tema kegiatanku sehari hari di sekolah peserta didik masih kesulitan ketika mengikuti pembelajaran menulis kalimat sederhana. Penulis memperoleh data hasil belajar menulis kalimat sederhana peserta didik masih dibawah KKM (Kriteria ketuntasan maksimal) yaitu dibawah 75. Masih banyak siswa yang mendapat nilai 40,50,60,65,70. Menurut peneliti faktor - faktor yang mempengaruhi proses belajar mengajar adalah tujuan pembelajaran, anak didik, bahan ajar pembelajaran, media pembelajaran, metode pembelajaran, dan evaluasi. Dari faktorfaktor tersebut yang mempengaruhi kegiatan belajar mengajar, bahan ajar tematik sebagai sumber belajar diyakini dapat mengatasi masalah pembelajaran pada tema kegiatanku sehari - hari di sekolah siswa kelas II SD yang masih dibawah KKM. Seperti yang diungkapkan oleh Prastowo (2012: 17) yang menyatakan bahwa bahan ajar pada dasarnya merupakan segala bahan yang disusun secara sitematis, yang menamplkan sosok utuh dari kompetensi yang akan dikuasai siswa dan digunakan dalam proses pembelajaran dengan tujuan perencanaan dan penelaahan implementasi pembelajaran.

Yuniadi Siska (2018) mengatakan bahwa hasil pengembangan bahan ajar tematik berbasis kearifan lokal pada tema daerah tempat tinggalku untuk peserta didik kelas IV sangat layak dan efektif digunakan. Selanjutnya penelitian pengembangan Eka Misminarti (2016) mengatakan bahwa pengembangan bahan ajar melalui cerita islami secara efektif meningkatkan hasil belajar siswa,dan berdasarkan hasil validasi ahli bahwa pengembangan bahan ajar layak digunakan

Nurgiyantoro (2013:159), peran buku cerita bergambar sangat penting, karena dapat membantu siswa belajar tentang alam, mengenal orang lain,dan pengembangan perasaan.

Zaenal Fajri (2015) mengatakan bahwa bahan ajar tematik berbasis konstekstual dapat diterapkan guru dan siswa sebagai sumber belajar alternative dan secara praktis dapat digunakan dalam kegiatan belajar mengajar. Selanjutnya Ariga Bahrodin mengatakan bahwa hasil pengembangan buku ajar tematik berbasis model pembelajaran Triprakoro kelas IV semester II MIN Bandar Kidul Kediri dikategorikan tingkat sangat valid dan layak digunakan.

Berdasarkan hasil pengamatan peneliti mengenai pembelajaran yang kurang optimal, maka peneliti memberikan jalan keluar dengan mengembangkan bahan ajar tematik kelas II sekolah dasar untuk menciptakan suasana belajar yang gembira. Dengan pengembangan bahan ajar tematik ini diharapkan dapat menjadi salah satu alternative model pembelajaran yang dapat digunakan guru dalam menyampaikan pembelajaran pada tema kegiatanku sehari - hari di sekolah untuk siswa kelas II sekolah dasar.

Penelitian ini idealnya diujicobakan pada beberapa sekolah di Samarinda, karena keterbatasan waktu, dan masa pandemic maka peneliti hanya mengujicobakan di SD Negeri No. 024 Samarinda Utara yang terletak di jalan Bengkuring Raya Luar blok C kecamatan Samarinda Utara Kota Samarinda, dikarenakan belum tersedianya media pembelajaran yang representatif.

Atas dasar hal tersebut, peneliti melakukan penelitian tindak lanjut dengan judul "Efisiensi Pengembangan Bahan Ajar Tematik Siswa Kelas II Sekolah Dasar Di Samarinda". Pada tema Tugasku Sehari-hari sub tema Tugasku Sehari-Hari di Sekolah. Pengembangan media pembelajaran secara sistematis diperlukan dalam pembelajaran agar siswa dapat menguasai setiap kompetensi secara tuntas.

\section{Metode}

Jenis penelitian ini merupakan penelitian pengembangan Research and Development (R\&D). Pendidikan dengan model pengembangan ADDIE dengan pengembangan bahan ajar tematik berupa buku cerita bergambar di SD Negeri Samarinda kelas II Tahun 2019. model ADDIE dikembangkan oleh Dick dan Carry (1996). Tahap yang harus dilakukan pada pengembangan model ADDIE adalah analysis, design, development, implementation,evaluasi. Pengembangan bahan ajar tematik siswa kelas II SD Negeri Samarinda, dimana temuan penelitian 
dimanfaatkan untuk produk baru kemudian secara sistematik diuji cobakan di lapangan, dievaluasi, dan diperbaiki sampai memenuhi kriteria kelayakan, keefektifan, dan standar tertentu. Tahapan perancangan pengembangan model ADDIE Metode penelitian dan pengembangan juga didefinisikan sebagai suatu metode penelitian yang digunakan untuk menghasilkan produk tertentu dan menguji keefektifan produk tersebut (Sugiyono, 2011: 297). Berdasarkan pendapat tersebut dapat di katakan bahwa penelitian pengembangan dalam bidang pendidikan dan pembelajaran merupakan model penelitian yang bertujuan untuk mengembangkan dan memvalidasi produk pendidikan dan pembelajaran untuk meningkatkan dan mengembangkan mutu pendidikan dan pembelajaran secara efektif dan adaptable.

\section{a) Tahap Analisis ( Analysis )}

Kegiatan analisis dilakukan peneliti dengan melakukan pengamatan dilapangan, peneliti mengajar di kelas II dan melakukan wawancara terstruktur terhadap guru kelas II mengenai kesulitan yang dihadapi guru - guru kelas II dalam pembelajaran tematik. Adapun yang yang dilakukan peneliti pada tahap ini adalah: (1) Penentuan Materi yaitu dari hasil analisis kebutuhan bahan ajar didapatkan beberapa materi yang muncul untuk dikembangkan dalam bahan ajar tematik. Materi kemudian dipilh dan disesuaikan dengan silabus. Dari hasil wawancara didapatkan bahwa pembelajaran pada tema kegiatanku sehari - hari di sekolah adalah salah satu materi yang disebutkan oleh guru sebagai materi yang belum tercapai hasil belajar yang diinginkan; (2) Studi Pustaka Pengembangan Bahan Ajar Tematik pengembangan bahan ajar tematik dilakukan dengan studi pustaka mengenai bahan ajar tematik. Pendekatan pembelajaran yang digunakan, langkah - langkah pengembangan bahan ajar tematik dan evaluasi dari pengembangan bahan ajar. Hal ini akan menjadi acuan bagaimana selanjutnya bahan ajar tematik tersebut dikembangkan; (3) Analisis Standar Isi Pembelajaran Tematik Kelas II pada tahap ini dilakukan analysis terhadap standar isi kurikulum 2013. Tahap ini bertujuan untuk menentukan materi berdasarkan KI dan KD dalam kurikulum kelas II Sekolah Dasar.

\section{b) Tahap Desain}

Pada tahap ini peneliti menyusun bahan ajar tematik. Peneliti mulai merancang desain produk bahan ajar pembelajaran dengan konsep sesuai dengan materi dan kompetensi dasar yang telah ditetapkan. Langkah - langkah sebagai berikut: (1) menetapkan judul buku cerita bergambar; (2) menyiapkan buku - buku sumber dan buku referensi lainnya; (3) melakukan identifikasi terhadap kompetensi dasar; (4) serta merancang bentuk kegiatan pembelajaran yang sesuai; (5) mengidentifikasi indicator pencapaian kompetensi dan merancang bentuk dan jenis penilaian yang akan dsajikan; (6) merancang format penulisan buku cerita bergambar. Penyusunan Rencana Pelaksanaan Pembelajaran berdasarkan kurikulum 2013, dengan langkah langkah sebagai berikut: (1) mencantumkan identitas; terdiri dari: nama sekolah, mata pelajaran, kelas, semester, standark kompetensi, kompetensi dasar, indikator dan alokasi waktu; (2) merumuskan tujuan pembelajaran; (3) menentukan materi pembelajaran; Menentukan metode pembelajaran; menetapkan kegiatan pembelajaran; (6) memilih sumber belajar; (7) menentukan penilaian.

\section{c) Tahap Pengembangan ( Development)}

Peneliti mengembangkan media sesuai desain yang telah dirancang. Pada tahapan ini, peneliti membuat rancangan desain yang telah dibuat pada tahapan sebelumnya, dalam hal ini menggunakan program aplikasi desain grafis yakni Adobe Photoshop CS6. Teknik yang digunakan digital drawing dan coloring melalui perangkat PC dan media input drawing tablet Wacom ctl490 small. Setelah proses mendesain selesai, langkah selanjutnya dilakukan penyusunan rancangan media buku cerita bergambar yang akan diterapkan. Adapun langkah - langkah dalam pembuatan pengembangan media adalah sebagai berikut:(1) sketsa gambar yang diinginkan, (2) inking, (3) pemberian warna dasar, (4) shading dan detailing background, (5) finishing dengan menambahkan beberapa efek, (6) proses layouting Sebelum dilakukannya penerapan langsung dalam pembelajaran. Dalam tahapan pengembangan ini dilakukan hal sebagai berikut: (1) uji kelayakan bahan ajar tematik buku cerita bergambar yang sudah dibuat harus melalui tahap uji kelayakan oleh dosen ahli materi dan dosen ahli media pembelajaran. Tahapan ini untuk menentukan kelayakan bahan ajar buku cerita bergambar layak untuk dpergunakan; (2) Revisi Bahan Ajar Tematik Hasil uji kelayakan menunjukkan kekurangan dari buku cerita bergambar yang telah dibuat, setelah validasi ini akan dilakukan revisi sebelum diujicobakan;(3) Pembuatan Instrumen untuk mendapatkan tanggapan guru terhadap bahan ajar buku cerita bergambar yang dikembangkan dibuat beramaan dengan buku cerita bergambar, setelah produk dibuat, dapat 
dilanjutkan dengan pengambilan data berupa tanggapan guru terhadap buku cerita bergambar yang telah dikembangkan.

\section{d) Tahap Implementasi (Implementation)}

Tahap implementasi dilakukan uji coba produk pada siswa kelas II SDN.NO.024 Samarinda Utara sebanyak 32 peserta didik. Untuk menghasilkan produk media pembelajaran yang baik maka perlu diadakan uji coba terhadap produk tersebut. Uji coba dilakukan untuk mengetahui kekurangan yang ada pada media pembelajaran yang telah dibuat, Pada tahap ini dilakukan revisi jika diperlukan. Peserta didik juga diberikan tes setelah penggunaan media untuk mengetahui kelayakan media. dan melihat efektifitas produk media tersebut bila digunakan untuk sasaran peserta didik yang dituju.

\section{5) Tahap Evaluasi (Evaluation)}

Pada tahap evaluasi merupakan proses menganalisis media apabila pada tahap implementasi masih terdapat kekurangan atau kelemahan. Pada tahap ini, penilaian bahan ajar tematik yang di kembangkan adalah aspek kelayakan, keefektifan serta tingkat efisiensi media yang telah dikembangkan.

Pada langkah ini pengembang melakukan klarifikasi data yang didapatkan dari angket yang berupa tanggapan dari guru terhadap media yang dikembangkan dan kevalidan media dari validator.

Jika tidak ada revisi lagi, maka media layak digunakan. Pada tahap ini dilakukan uji kelayakan produk dalam proses pembelajaran, Uji efektifitas, dan uji efisiensi media dalam proses pembelajaran. Implementasi produk baru setelah tahap pengembangan mulai dari tahap desain, uji coba produk sampai dengan revisi akhir. Jika tidak ada revisi lagi, maka media layak digunakan. Pada tahap ini dilakukan uji kelayakan produk dalam proses pembelajaran, Uji efektifitas, dan uji efisiensi media dalam proses pembelajaran. Implementasi produk baru setelah tahap pengembangan mulai dari tahap desain, uji coba produk sampai dengan revisiakhir.

Uji efisiensi bahan ajar tematik buku cerita bergambar di fokuskan pada aspek waktu dengan membandingkan antara waktu yang diperlukan dengan waktu yang digunakan dalam proses pembelajaran, sehingga di peroleh rasio dari hasil perbandingan tersebut. Uno (2008:21) mengatakan bahwa efisiensi pembelajaran bisa diukur dengan rasio antara keefektifan dan jumlah waktu yang dipakai atau dipergunakan si belajar dan / jumlah biaya pembelajaran yang dipakai. Adapun rumus yang digunakan untuk menghitung efisiensi adalah:

$$
\text { Efisiensi }=\frac{\text { Waktu yang di perlukan }}{\text { Waktu yang dipergunakan }}
$$

\section{Hasil dan Pemmbahasan}

Hasil penelitan pengembangan bahan ajar tematik untuk siswa kelas II Sekolah dasar ini dilakukan dengan langkah - langkah ADDIE. Hasil pengembangan dengan mengikuti langkah - langkah sebagai berikut:

\section{Tahap Analisis}

Langkah awal dalam pengembangan bahan ajar tematik melalui tahap analysis sehingga menghasilkan analisis kebutuhan yang diperoleh data keadaan umum SDN. 024 Samarinda Utara terdiri dari guru kelas II ada 4 orang. Untuk mengetahui masalah dan potensi di sekolah ini peneliti mengumpulkan informasi dengan menggunakan angket observasi dan wawancara terstruktur kepada guru, kepala sekolah, dan siswa di tempat tersebut dan hasil observasi bisa dilhat pada tabel di bawah ini

\begin{tabular}{|l|l|l|}
\hline No & \multicolumn{1}{|c|}{ Aspek Identitas } & \multicolumn{1}{|c|}{$\%$ Skor } \\
\hline 1 & Pangkat / Golongan & $16 \%$ IIIA \\
\hline 2 & PNS / Non PNS & $62 \%$ PNS 38\% Non PNS \\
\hline 3 & Jenis Kelamin & $84 \%$ Wanita dan 16\% Laki - laki \\
\hline 4 & Pendidikan terakhir & $91 \%$ S1 9\% D2 \\
\hline 5 & Sekolah Tempat Mengajar & $100 \%$ SDN 024 Samarnda Utara \\
\hline 6 & Perguruan Tinggi & Universitas Mulawarman 17\% 65\% \\
& & Universitas Terbuka 18\% PGRI \\
\hline 7 & Jurusan Pendidikan & $74 \%$ PGSD Ekonomi 18\% 2\% \\
& & $\begin{array}{l}\text { PKN } \% \text { BAHASA INDONESIA } \\
4 \% \text { BAHASA INGGRIS }\end{array}$ \\
\hline
\end{tabular}

Data guru menunjukkan masih ada guru kelas yang tidak linier sebesar $26 \%$, hal ini dapat mempengaruhi proses pembelajaran. Proses belajar mengajar akan lebih baik apabila guru tersebut memiliki latar belakang pendidikan yang linier sesuai dengan disiplin keilmuan dan keahliannya. Apabila proses belajar mengajar berjalan dengan baik maka akan mempengaruhi prestasi belajar peserta didik . Oleh karena itu, seorang pendidik mempunyai pengaruh yang sangat besar terhadap keberhasilan belajar peserta didik. 


\begin{tabular}{|c|c|c|c|}
\hline \multirow[t]{2}{*}{ No } & \multirow[t]{2}{*}{ Aspek penilaian } & \multicolumn{2}{|c|}{ Skor (\%) } \\
\hline & & $\begin{array}{l}\text { Ya/ } \\
\text { Sudah }\end{array}$ & $\begin{array}{l}\text { Tidak / } \\
\text { Belum }\end{array}$ \\
\hline 1 & $\begin{array}{l}\text { Sekarang ini telah banyak dikembangkan } \\
\text { bahan ajar tematik? }\end{array}$ & $10 \%$ & $90 \%$ \\
\hline 2 & $\begin{array}{l}\text { Bahan ajar tematik yang sering bapak/ibu } \\
\text { gunakan pada tema kegiatanku sehari - } \\
\text { hari di sekolah? } \\
\text { a. Buku dari pemerintah yang } \\
\text { sudah ada di sekolah } \\
\text { b. Mengembangkan sendiri bahan } \\
\text { ajar tematik }\end{array}$ & & $80 \%$ \\
\hline 3 & $\begin{array}{l}\text { Bagaimana Bapak/ lbu mempersiapkan } \\
\text { bahan ajar tematik pada tema kegiatanku } \\
\text { sehari - hari di sekolah yang akan } \\
\text { digunakan di kelas? } \\
\text { a. Membuat sendiri } \\
\text { b. Mendownload dari internet } \\
\text { c. Menggunakan buku dari } \\
\text { d. Lemerintah }\end{array}$ & $\begin{array}{l}20 \% \\
40 \% \\
80 \%\end{array}$ & $80 \%$ \\
\hline 4 & $\begin{array}{l}\text { Apakah Bapak/ lbu pernah membuat } \\
\text { bahan ajar tematik pada tema kegiatanku } \\
\text { sehari - hari di sekolah? }\end{array}$ & $20 \%$ & $80 \%$ \\
\hline 5 & $\begin{array}{l}\text { Apa ada kendala yang muncul pada saat } \\
\text { Bapak/ Ibu membuat bahan ajar tematik? }\end{array}$ & $80 \%$ & \\
\hline 6 & $\begin{array}{l}\text { Selama ini bagaimana rata - rata hasil } \\
\text { belajar pada tema kegiatanku sehari - hari } \\
\text { di sekolah? }\end{array}$ & $45 \%$ & \\
\hline
\end{tabular}

Dari hasil analisis tabel diatas menunjukkan bahwa Pembelajaran tematik pada tema kegiatanku seharihari di sekolah guru hanya berpedoman pada buku guru yang telah disediakan pemerintah. Berdasarkan hal tersebut peneliti mengembangkan bahan ajar tematik berupa buku cerita bergambar.

Alasan peneliti mengembangkan bahan ajar tematik buku cerita bergambar adalah agar bahan ajar buku cerita bergambar tersebut dapat membantu menyajikan suatu kejadian atau peristiwa secara kronologis dengan menghadirkan orang, benda, dan latar. Kronologi atau urutan kejadian peristiwa tersebut dapat memudahkan siswa untuk menuangkan idenya dalam kegiatan menulis kalimat karena dengan membaca cerita, siswa dapat mengingat kemudian menulis apa yang telah dibacanya Peneliti memilih menggunakan software tersebut karena software memiliki kelebihan dan mudah dalam penggunaan

Analisis karakteristik siswa diperlukan untuk menyusun bahan ajar tematik yang sesuai dengan minat belajar siswa. Dalam penelitian ini, peneliti mengidentifikasi karakteristk siswa yang meliputi kemampuan awal siswa dan minat atau motivasi siswa dalam pembelajaran. Untuk mengetahui kemampuan siswa terhadap materi pembelajaran tematik pada tema kegitanku sehari - hari di sekolah, peneliti menggunakan pre test.

Pada tahap studi pustaka dilakukan analisis literature untuk dituangkan pada kajian teori. Berdasarkan data dan informasi yang diperoleh pada studi pendahuluan maka perencanaan yang dilakukan meliputi:(1) merumuskan tujuan pengembangan yang berfokus pada pengembangan bahan ajar tematik; (2) pengembangan bahan ajar tematik difokuskan pada tema tugasku sehari- hari sub tema tugasku sehari- hari di sekolah; (3) mengacu pada subtema tersebut meliputi materi pelajaran Bahasa Indonesia, Ppkn, dan Matematika; (4) bahan ajar tematik yang dikembangkan didasarkan pada kompetensi dasar yang ada pada silabus pembelajaran; (5) indicator karakter yang akan ditingkatkan yaitu karakter peduli dan tanggung jawab.

\section{Tahap Desain}

Selanjutnya dalam prosedur pengembangan media adalah tahap desain, tahap desain ini meliputi desain bahan ajar tematik buku cerita bergambar didasarkan pada hasil pengamatan dilapangan dan analisis kebutuhan yang telah disusun., pembuatan bahan ajar tematik sesuai desain produk yang telah dibuat, menyusun sumber bahan dan materi, serta pembuatan/penyusunan bahan ajar tematik buku cerita bergambar.penyusuanan draft dan layout. Pembuatan bahan ajar tematik buku cerita bergambar, tahapan ini meliputi: menyusun kompetensi dasar berdasarkan pada silabus dan Rencana Pelaksanaan Pembelajaran.

\section{Hasil Uji Efisiensi Bahan Ajar Tematik}

Berdasarkan perhitungan waktu yang biasa digunakan pada proses pembelajaran sesuai jam pelajaran rasio efisiensinya diperoleh: 70 menit/76 menit $=0,92$. Sedangkan perhitungan rasio efisiensi berdasarkan hasil uji coba lapangan diperoleh nilai rasio efisiensi 210 menit/185 menit $=1,13$. Klasifikasi nilai rasio efisiensi, maka pembelajaran tematik pada tema kegiatanku sehari - hari termasuk dalam klasifikasi efisiensi tinggi atau dapat dikatakan efisien. Nilai efisiensi dan klasifikasi dapat dilihat lebih rinci pada tabel berikut:

\begin{tabular}{|c|c|c||}
\hline $\begin{array}{c}\text { Hasil Analisis } \\
\text { Nilai Efisiensi }\end{array}$ & Klasifikasi & $\begin{array}{c}\text { Tingkat } \\
\text { Efisiensi }\end{array}$ \\
\hline 1,13 & Tinggi & Efisien \\
\hline
\end{tabular}

Berdasarkan tabel perolehn nilai efisiensi yang diperoleh dari hasil uji coba lapangan dapat 
disimpulkan bahwa bahan ajar tematik yang telah dibuat dapat dikatakan sangat efisien digunakan dikelas II Sekolah Dasar

\section{Pembahasan}

Berdasarkan hasil uji analisis dapat diketahui bahwa pengembangan bahan ajar tematik termasuk kriteria sangat layak, efektif, dan efisien digunakan di kelas II Sekolah Dasar. Penelitian Eka Wahyuni (2015) Pengembangan Bahan Ajar Tematik Pendamping Guru dengan Model Webbed Untuk Sekolah Dasar Kelas II. Berdasarkan hasil penelitian pengembangan yang ditunjukkan bahwa produk yang telah dikembangkan layak digunakan sebagai buku pendamping guru dalam mengajar

Kelayakan bahan ajar tematik yang telah dikembangkan diperoleh dari penilaian validator ahli yakni ahli materi, ahli desain bahan ajar, dan praktisi guru. Berdasarkan hasil penilaian pada tabel 4.6 di atas dan rata - rata dari validator ahli yakni memperoleh rata - rata 4,66, adapun persentase penilaian dari validator ahli menunjukkan kevalidan sebesar 92,14\% sehingga sesuai persentase pencapaian kelayakan media pembelajaran termasuk pada interpretasi sangat layak. Dengan demikian bahan ajar tematik dapat digunakan sebagai bahan ajar tematik di kelas II Sekolah Dasar.

Perhitungan efisiensi bahan ajar tematk yang telah dikembangkan diperoleh dari proses pembelajaran dengan menggunakan perhitungan waktu yang digunakan dalam proses pembelajaran menulis kalimat sederhana. Nilai efisiensi berdasarkan tabel 4.8 bahan ajar tematik termasuk dalam klasifikasi efisiensi tinggi.

Penelitian Srikandi Octavianti (2017) Pengembangan Bahan Ajar Tematik Dalam Implementsi Kurikulum 2013 Kelas I Sekolah Dasar. Hasil penelitian pengembangan bahan ajar tematik menunjukkan bahwa terjadi perubahan prestasi belajar peserta didik kearah yang lebih baik setelah menggunakan activing book produk pengembangan yang dihasilkan. Penelitian Etikasari Dian (2014) Pengembangan Buku Ajar Tematik Berbasis Model Pembelajaran Triprakoro kelas IV semester II Min Bandar Kidul . Hasil penelitian menunjukkan bahwa pengembangan buku ajar tematik berbasis model pembelajaran Triprakoro kelas IV semester II Min bandar kidul kriteria yang sangat layak digunakan dalam pembelajaran tematik di kelas IV Sekolah Dasar.

Penelitian selanjutnya Muhimah Ngaziz (2014) dengan judul penelitian Pengembangan Bahan Ajar Tematik Terpadu dengan Tema Pariwisata Pada Kelas II MI Ma'Arif Sukun Malang. Hasil pengembangan bahan ajar tematik menunjukkan bahwa pengembangan bahan ajar tematik terpadu layak digunakan dapat memberikan pengalaman dalam belajar secara efektf. Sebagaimana yang di ungkapkan oleh Ahmadi (2010:159) yang mengatakan bahwa bahan ajar adalah segala bentuk bahan yang digunakan untuk membantu guru / instruktur dalam melaksanakan kegatan belajar mengajar di kelas. Bahan yang dimaksud bias berupa bahan tertulis, maupun bahan tidak tertulis. membangkitkan motivasi dan rangsangan kegiatan belajar serta membawa pengaruh psikologis pada siswa.

Pengembangan media pembelajaran yang telah dilakukan oleh para peneliti menunjukkan pengaruh yang sangat signifikan terhadap hasil belajar peserta didik. Dari uraian - uaraian tersebut diatas menunjukkan hasil penelitian pengembangan media pembelajaran yang valid / layak, efektif dan efisien digunakan dalam pembelajaran.

Bahan ajar tematik mempunyai tujuan meningkatkan motivasi peserta didik selain itu media juga harus merangsang peserta didik mengingat apa yang sudah dipelajari.buku cerita bergambar yang telah dikembangkan dapat mengaktifkan peserta didik dalam memberikan tanggapan, umpan balik dan mendorong peserta didik melakukan praktek - praktek dengan benar. Prastowo (2014:17) mengatakan bahwa bahan ajar adalah bahan - bahan atau materi pelajaran yang disusun secara sistematis, yang digunakan guru dan peserta didik dalam proses pembelajaran.

Pelaksanaan proses pembelajaran dengan menggunakan bahan ajar, keefektifan mengacu pada tingkatan konsistensi pengalaman dengan tujuan yang akan dicapai. Tingkat keefektifan bahan ajar yang dihasilkan dapat di ukur dengan melihat seberapa besar penghargaan yang diterima siswa setelah melalui beberapa rangkaian proses pembelajaran, serta adanya keinginan siswa untuk terus menggunakan buku cerita bergambar yang telah dikembangkan tersebut. Abdul Majid (2006:170) mengtakan bahwa sumber belajar ditetapkan sebagai informasi yang disajikan dan disimpan dalam berbagai mediiayang dapat membantu siswa dalam belajar sebagai perwujudan dari kurikulum.

Bahan ajar dikatakan efisien apabila bahan ajar terebut dapat meniptakan lingkungan belajar yang kondusif sebagaimana yang dikemukakan oleh Hamdani (2011:121) mengatakan bahwa bahan ajar merupakan 
pedoman bagi siswa yang akan mengarahkan semua aktivitasnya dalam proses pembelajaran, sekaligus merupakan substansi kompetensi yang seharusnya dpelajari atau dikuasainya.. Dengan adanya bahan ajar diharapkan proses belajar mengajar bisa lebih efisien.

\section{Kesimpulan}

Berdasarkan hasil penelitian dan pembahasan yang berkaitan dengan pengembangan bahan ajar tematik untuk siswa kelas IISD. Berikut simpulan yang berkaitan dengan pengembangan bahan ajar tematik:

1) Cara mengembangkan bahan ajar tematik dilakukan berdasarkan prosedur pengembangan ADDIE yang terdiri dari lima tahapan yaitu: analysis, design, development, implementation, serta evaluation, agar guru memiliki pedoman dalam mengembangkan bahan ajar tematk.

2) Kelayakan pengembangan bahan ajar tematik buku cerita bergambar dapat dilihat dari hasil validasi tim ahli atau validator menghasilkan nilai presentasi $90 \%$ dengan kategori hasil validasi bahan ajar tematik termasuk kriteria sangat valid atau sangat layak digunakan dalam pembelajaran di kelas II SD. Hal ini juga didukung dari hasil respon guru dan sswa yang positif dengan nilai kategori sangat layak digunakan sehngga dapat digunakan guru sebagai acuan untuk mengembangkan bahan ajar tematik.

3) Kefektifan pengembangan bahan ajar tematik dapat dilihat pada perolehan rata - rata pretest dan posttest yang menunjukkan ketuntasan klasikal peserta didik sehingga bahan ajar tematik termasuk kategori sangat efektif dgunakan pada siswa kelas II SD.

4) Efisiensi penggunaan bahan ajar tematik buku cerita bergambar dapat dilihat pada perolehan nilai uji efisensi penggunaan bahan ajar tematik termasuk kedalam kriteria sangat efisien karena memperoleh nilai 1.27. Nilai uji efisiensi di atas 1 adalah sangat efisien.

\section{Referensi}

Depdiknas. (2006). Kurikulum Pendidikan Dasar. Jakarta: Depdiknas

Dick, W and Carrey, L. (1985). The Systematic Design Instruction. Secon Edition. Glenview. Illinois: Scott. Foreman and Company

Hamdani. (2011). Strategi Belajar Mengajar. Bandung: Pustaka Setia

Nurgiyantoro, B. (2013). Penilaian Pembelajaran Bahasa Berbasis Kompetensi. Yogyakarta: Badan Percetakan Fakultas Ekonomi Negeri Yogyakarta.

Popp, Marcia S. (2008). Teaching Languages and Literatures in Elementary Classrooms. London: Lawrence Erlbaum Associates Inc

Putrayasa. (2008). Analisis kalimat Fungsi, Kategori dan peran. Bandung: Refika Utama

Purwanto. 2010.Evaluasi Hasil Belajar. Yogyakarta: Pustaka Pelajar

Santosa, Puji. (2011). Materi dan Pembelajaran Bahasa Indonesia SD. Jakarta: Universitas Terbuka

Solchan. (2011). Pendidikan Bahasa Indonesia. Jakarta: Universitas Terbuka

Solchan, T,W, dkk.(2014). Pendidikan Bahasa Indonesia di Sekolah Dasar. Banten: Universitas Terbuka

Sugiyono. (2013). Metode Penelitian Pendidikan Pendekatan kuantitatif, dan R \&D. Bandung: Alfabeta

Sugiyono. (2015). Metode Penelitian Kombinasi. Bandung: Alfabeta

Zuhdi, Darmiyati. (2008). Pendidikan Bahasa dan Sastra Indonesia di Kelas Rendah. Jakarta: Depdikbud 